\title{
Aristocratic house offarmers: the topos of the de re rustica in Sá de Miranda's verse epistles
}

\author{
Ricardo Hiroyuki Shibata[1]
}

\begin{abstract}
This paper analyses the Francisco de Sá de Miranda's verse epistles according to some historical boundaries. It is clear that Sá de Miranda's main reason lied on the defense of "time of memory", which must be preserved, against the Portuguese expansion and the present time. To do so, Sá de Miranda proposed some doctrinal aspects of "economics" (oeconomia), "house" (oikos) and related subjects, whose vitality was reactivated in the Renaissance, through the literary translation of the so called de re rustica (subject of farmers and peasants). From classical times to the Modern Age, the "house" (oikos) was not only a question of family administration and conservation of the real state, but also of agriculture and friendship bonds. Keywords: Renaissance; Portuguese expansion; Modern Age.
\end{abstract}

Casa aristocrática de lavradores: o topos do de re rustica nas epístolas em verso de Sá de Miranda

\section{Resumo}

Este artigo procura investigar algumas coordenadas epocais presentes nas epístolas em verso de Francisco de Sá de Miranda (1481-1558).É possível afirmar que a argumentação principal de Sá de Miranda reside na defesa de um “tempo da memória”, que deve ser preservado, em oposição estratégica às vicissitudes da expansão marítima portuguesa e do tempo presente. Isso se faz a partir da mobilização da doutrina da "economia" (oeconomia), da "casa" (oikos) e de matéria correlata, cuja vitalidade foi reativada pelo Renascimento, com tradução literária nos lugares-comuns do de re rustica (assunto de agricultura e de camponeses). Dos tempos clássicos até a Idade Moderna, todo esse conjunto normativo não tratava somente das questões de administração da família e da conservação do patrimônio, mas também da agricultura e das relações de amizade.

Palavras-chave: Renascimento; navegações portuguesas; Idade Moderna.

La casa aristocrática de labradores: el topos del de re rustica en las epístolas en verso de Sá de Miranda

\section{Resumen}

Este artículo busca investigar algunas coordenadas de época presentes en las epístolas en verso de Francisco de Sá de Miranda (1481-1558). Es posible argüir que el principal argumento de Sá de Miranda es la defensa de un "tiempo de la memoria", que debe preservarse, en oposición estratégica a las vicisitudes de la expansión marítima portuguesa y del momento actual. Esto se hace desde la movilización de la doctrina de la "economía" (oeconomia), la "casa" (oikos) y asuntos conexos, cuya vitalidad fue reactivada por el Renacimiento, con traducción literaria en los lugares comunes del de re rustica (tema de la agricultura y los campesinos). Desde la Época Clásica hasta la Edad Moderna, todo este conjunto de normas no sólo abordaba los problemas de gestión de la familia y la conservación del patrimonio, sino también de la agricultura y las relaciones de amistad.

Palabras clave: Renacimiento; navegaciones portuguesas; Edad Moderna.

\section{Maison aristocratique des agriculteurs: les topos de re rustica dans les épîtres de Sá de Miranda}

\section{Résumé}

Cet article examine certaines coordonnées d'époque présents dans les épîtres en vers de Sá de Miranda (1481-1558). On peut faire valoir que le principal argument de Sá de Miranda est la défense d'un «temps de la mémoire», qui doit être préservé dans l'opposition stratégique pour les vicissitudes de l'expansion maritime portugaise et du temps présent. Cela se fait à partir de la mobilisation de la doctrine de «léconomie» (oeconomia), la «maison» (oikos) et des questions connexes, dont la vitalité a été réactivée par la Renaissance, avec la traduction littéraire dans les lieux communs de re rustica (une affaire de l'agriculture et les agriculteurs). De l'Antiquité à lépoque moderne, cet ensemble de règles n'était pas seulement les questions de gestion de la famille et de la conservation du patrimoine, mais aussi de lagriculture et des relations amicales. Mots clés: Renaissance; navigations portugaises; Âge Moderne. 
Blessed is he who lives and dies in His home! For in His home even the poor are kings.

Lope de Vega, El Duque de Viseo.

I

nside the literary practices of ethical-political nature of the Modern Age, the theme "home" (oikos) and its correlates (e.g., family, inbreeding, marriage bonds) is absolutely recurrent and strategical, although it has inspired little interest to historiography up to now. Particularly, from a given 16th-century Iberian context, I believe this set of commonplace is applied as rhetorical places of inventio of many correspondences in the period of navigations - many of those under an admonishing character.

It is precisely, in this sense, that the Francisco de Sá de Miranda's verse epistles (1481-1558) are particularly striking when criticizing the Portuguese expansion overseas and trading as a way of gathering money and accumulating wealth. Besides its negative moral effects, Sá de Miranda understands it is absolutely unworthy to the noble lineage man to get involved in "merchandise treating", also considering there are other more suitable ways to old traditions and the most prestigious values of blood aristocracy.

In several speeches of the Old Regime, in Portugal, the reference to a "time in memory" is noticeable, which must be preserved, since it unifies and stabilizes the various social bonds established within the political community. And it is in the name of this time in the past that Sá de Miranda evokes the classical topoi of oeconomia, and in particular, how it was understood by Xenophon thought and other theorists of correlate matters.

As it is known, the books of Oeconomicus, by Xenophon, whose influence during Humanism was surprising, are divided into two parts: the first, in which the young and wealthy Critobolo asks Socrates which is the best way to manage his assets, and the second, in which Socrates tells Critobolo the conversation he had with the noble and wealthy Ischomachus. From both of those, Critobolo will be able to identify essential elements that constitute the "téchne oeconomica" and all its advantages for the family, for himself, and for the politics. The economy being discussed is not the political economy developed from the 18th century on and connected to the birth of the concept of a Burgeois state with the analytical description of the market rules.

In fact, the old art of economy is the knowledge of the typical "family man" and constitutes, in its great interpretative lines, a true doctrine of the "home as a complex", whose scope defines the ways of not only raising founds and gathering money, but, most of all, the ways to a good family management, of the man as the head of the household, the wife, the servants, the friends, and the management of family assets, consisting of furniture and real estate. Aristotle, in Politica (I, 3, 1253b 3-14), stated that all central aspects of the economy are derived from the parts that constitute the home. He would particularly stress

'Francisco de Sá de Miranda, Poesias de Francisco de Sá de Miranda, v. 238, Lisboa, INCM, 1989, p. 243 
the fact that three kinds of relationships would maintain and stabilize the house and the family in order to fulfill their purposes: master-slave, husband-wife, and father-son. Thus, the economy, in short, for Aristotle, consisted of three possible functions to be performed by the noble and aristocratic man: the art of the master, the husband, and the father. ${ }^{2}$

The economy, known as the doctrine of the oikos, was, then, the area to exercise a specific form of power - the one of the despostes or pater familias, a character that does not resemble the sentimental and romantic figure of the man who lives for his children and wife. For the old thinking, the paternal power was shaped, first of all, a sphere of specific power (the opposition was made by the scope of the politics), with fairly well determined limits and obligations, which was held by the use of the art of nobility, similarly to the ability of man to master oneself, in the ethical field, and the of the citizen to intervene in matters related to the governance of the city, in the political field. ${ }^{3}$ The strength of this tradition may be observed in the words of De Senectute (XVII, 59), by Cicero, author of important treaties for the humanist thinking, in which he refers to Xenophon as the origin of all economic thinking: in eo libro qui est tuenda rei familiari ("that which summarized the doctrine of the home and the family").

It is precisely based on this doctrine that Sá de Miranda prescribes which are the activities worthy of the noble and virtuous master of the house and head of the family, not only as for his duty on raising the necessary funds in order to provide for his family, but also regarding the art of spending money, as an expression of the virtue of distributive justice, liberality, and magnificence. In this sense, for Sá de Miranda, according to the Horatian topos of fugere urbem ("escape from the city"), the court's retreat into the countryside means the "freedom" to rule what is rightfully theirs (and not the search for honor and privileges obtained by the service to another master; for him, this was but "servitude"). In addition, Sá de Miranda signaled that the only decent way to gain wealth and to remain financially independent was to dedicate oneself to agriculture.

This is particularly clear when, in the letter "To Antonio Pereira", Sá de Miranda reminds the life these two true friends were engaged in the farm of Mr. de Bastos amidst frugal meals and conversations. The details of this strong relation are given by the disallowance to the Ofortunatos nimium, sua si bona norint/agricolae ("too happy peasants would be, if they only knew of the riches they have") of the Geórgicas (II. 457-458) by Virgil. Or, to point out otherwise, according to the same old economic matrix, with the El catón en latin y en romance, by Gonzalo García de Sancta María, all those who wish to unveil the real meaning to agriculture practice should read the pages by Virgil:

\footnotetext{
2See, for example, Rafaello Volaterrano, Commentariorum urbanorum... Oeconomicus Xenophontis, In: Scriptores rei rusticae, Veneza, Aldo Manúcio, 1514 (Seção de Obras Raras/Biblioteca Nacional do Rio de Janeiro, n. 213, 2, 14).

${ }^{3}$ Christopher Dyer, "Alternative approaches to the history of agriculture", Past \& Present, vol. 68, 2000, p. 254 -262.
} 
Si la arte quisieres de la agricultura

Saber: leeras aquel gran Mantuano:

Poeta Virgilio: ahun q[ue] pagano.

Mas si quisieres quiçá la natura

Saber de las hyerbas: difficil: [e] escura

Hacer auctor excellente: [e] approbado

Te lo díra por su verso: [e] dictado

Muy claro. sin glosa: [e] sin outra figura. ${ }^{4}$

Or, again, in order to refer to the enormous importance of these topos, it is enough to estate with Sá de Miranda, from the disallowance of a sententious saying removed from the "Preface" of De agricultura, by Cato ("et virum bonum quon laudabant, ita laudabant: bonum agricolam bonumque colonum", "the righteous men from before would only appreciate the virtue of the good grower and of the good farmer"): ${ }^{5}$

Our Greatest if one

Will praise, not of master,

Not of rich was the praise,

They will call thee a man of good,

And yet a good farmer.

Our people in praise

Which now seem vile,

To the good kings Sancho and Denis

Will call them farmers. ${ }^{6}$

According to some important Roman authors of agriculture treaties, Cato was famous by his deep traditionalism. For Columella, he was indeed a "peasant" author, worth saying, outdated in relation to other more modern authors who worried about more rational methods of using the land and organizing the labor processes. Some even considered the agriculture advices of Saserna to be more relevant than the ones of Cato, his father, and drew attention to the importance of the study of rural economy ("agricolatinoem diligentius erudierunt", "to diligently study the matter of agriculture").

However, Cato, in fact, was very little interested in the technical aspects of taking higher yield of the lands and the crops in the fields. He was interested in treating agriculture as an "art" and the only worthy source of income and living of a man born noble and his family. Cato, when comparing agriculture to other means of obtaining wealth - the commercial trade and money loans with interest (i.e., the other two most important sources of earning wealth in Roman times) - , used to state that there was no faster, easier,

\footnotetext{
4"If the art of agriculture you wish / to know: read the great Matuano, / the poet Virgil: even being a pagan. / And if you wish to know perhaps / the difficult and complicated nature of plants, / thou shall not find best excelled and approved author / l'd say his verses and sentences/are soberb without need for glosa or other explanations". Gonzalo G. Sancta María, El catón en latin y en romance, Zaragoza, Pablo Hurus, 1494, fl. ciijv (Fac-similar edition by Librerias Paris-Valencia, 1964).

5Maria Helena Rocha Pereira, "Uma descrição poética da Lisboa quinhentista”, Humanitas, n. 35-36, 1983 1984, p. 350.

${ }^{6}$ Francisco de Sá de Miranda, Poesias de Francisco de Sá de Miranda, v. 241-250, Lisboa, INCM, 1989, p. 246.
} 
safer, and more honest way to become rich. Pliny the Younger, however, in one of his epistles (II. 44), regretted that, after years of dedication and hard work, unfortunately, agriculture did not provide him with so much profit; however, despite the material failure, he had managed enough time, at least, to improve his virtues. ${ }^{7}$

As said by von Albrecht, the De agricultura of Cato is a heterogeneous text in which a first well-structured part about agriculture matters themselves is added to a second part in which practical advices on heteclite nature are given: cooking recipes and medical prescriptions to certain infirmities, praying, and reference to old habits and customs. The Roman literature historians state that it may be a late compilation or a home notebook of Cato, written for his personal use and afterwards some notes were added. Either way, it would be a handbook not only on agriculture, but also on rules for the maintenance and administration of the economic life, in which the moral value of agriculture practice and its whole range of topics (cattle breeding, tending to servants and family, preserving tradition, etc.) would comprise, including the preparation for military life. ${ }^{8}$

\section{For the old thinking, the parental power was shaped, first of all, in a sphere of specific power}

It seems clear for all Roman treatise that the Roman historians and Cato shared the same interest of writing about the maintenance of the noble Roman family in times of peace, after that, in times of war, the earnings came from looting (including the various ways of corso), the payment of rescue, the conquest of new territories, and the obtaining of slaves. The organization of domestic oeconomia gained importance for being considered, in both eras, the basis in which all the fundamental pillars for the society and its political structure would be set.

The increasing family wealth and, as a result, the success in the administration of the household were safe indexes in order to establish any ambition in a business career for the State. For Cato, living in a time in which the Roman power expanded dramatically throughout so many conquered territories and in which the number of "new rich" and their political influence increased greatly - similarly to the political context through which Portugal would go through in the 16th century - , this richness and this success could only come from a source as traditional as agriculture itself at the expense of any other way. Sá de Miranda also shared this thought:

'René Martin, Recherches sur les agronomes latins et leurs conceptions économiques et morales, Paris, Les Belles Lettres, 1971, p. 83 et seq.

${ }^{8}$ Michael von Albrecht, Historia de la literatura romana, Barcelona, Herder, 1994, p. 375 et seq 


\begin{abstract}
The valiant Roman
Before their will would be lost,

Where tended the choice between

Cincinatos and Serranos

That before their field would be?

And that greatness

Time does not want it to Moorish,

We see that the most noble

Surname of wealth

Not after, if not in the crop. ${ }^{9}$
\end{abstract}

It was also common to relate the arguments of Cato with the ideas of Hesiod in Os Trabalhos e ofDias, so much read and commented by the authors of matters of agriculture of the Roman Republic and Empire, especially regarding the legend of the two Erides. According to Hesiod, the bad Erides encourages men to live in constant disagreement, leading them to wars and fratricidal disputes; it is responsible for setting civic debates on fire, which nearly always end up in enmity and factionalism. The good Erides, born in the bowels of the Earth, on the contrary, encourages all human beings, especially mighty virtuous men, toward plowing, growing, and earning their living from agriculture, leading to wealth and happiness. This is how Hesiod warns, almost in a prayer, that one must have in their hearts the will to see the pentanes of the fields for the sustaining of the home (the "grain of Demeter") from what is produced by the earth and, only after that, it is possible to settle the disputes and claims on other people's business in public meetings, whose only advantage is to bring about concerns and disputes. ${ }^{10}$

\title{
The "ancient agronomists" were in fact writers engaged in the tradition of the highest Roman values, precisely that which made Rome the greatest empire of the world
}

For Sá de Miranda, writing exactly in this doctrinal sense, the gains obtained with trades and navigation are absolutely unworthy, not only because they bring evil effects from the moral point of view, but also because they are not consistent with the tradition of habits and customs, which should be preserved. It is to this that he addresses when he warns Antônio Pereira, his friend and neighbor, about the bad deal of trading the peace and delight of the country for the bustle of the city:

${ }^{9}$ Francisco de Sá de Miranda, Poesias de Francisco de Sá de Miranda, v. 241-250, Lisboa, INCM, 1989, p. 246. ${ }^{10 H e s i ́ o d o, ~ O b r a s ~ y ~ f r a g m e n t o s, ~ v . ~ 28-33, ~ M a d r i d, ~ G r e d o s, ~ 1997, ~ p . ~} 44$. 
In the village the villain lurks

Where there is name and heritage,

Living from their fatigue.

Glows the fragoa and the blacksmith

The time the rooster crows;

Bites the letter the shoemaker,

Yelling at the lazy lad

Who left from under the blanket.

Lives nobility from the outside

Safe, depopulated

Runs with the daring wolves,

Around where once

The field is kept free for the cattle,

From the adventurous bad people

That in the dark brings their dealing

Let free who wish

To sing at the fair at night

Or to sleep in the mulato. ${ }^{11}$

The dedication to agriculture, for Sá de Miranda, besides satisfactorily fulfilling the duty of obtaining material resources to ensure the survival of the family, was intended to ensuring the quiet environment necessary to the cultivation of virtues and the toughening of the spirit. As for this, he completely agrees with the ideas put forward by Gabriel Alonso de Herrera, one of the main repositories of this old thought regarding the moral benefits of agriculture activities, in his impressive Agricultura General (1513), whose critical fortune in the Iberian Peninsula has not yet been properly studied. ${ }^{12}$

The study of the work of Herrera, whose content the nobility of the 16th century would access through the collective reading aloud in the aristocratic ballrooms, causing enormous admiration due to the "the rules of his profession, which were not know other than the one from its greatests", specially because his practical knowledge and advices were based on many of the ancient Roman writings, serving as a fundamental guide for those who "have always done it this way" - the traditional motto guiding all his work. Maintaining the tradition "living the old way", as Sá de Miranda often insists - was commonplace in a society basically structured in a "time of the memory", which must be preserved at all costs. ${ }^{13}$

The classical writers of re rustica, or, as preferably named, the "ancient agronomists", were in fact writers engaged in the tradition of the highest Roman values, precisely that which made Rome the greatest empire of the world. And, for beyond technical considerations, it is common to find references to moral decay and to the forgetting of the wisdom of ancestors (mos maiorum), in which the problems of the land have been told to be associated with the changes in the social structure. In this sense, the conclusion to passing through

"Francisco de Sá de Miranda, Poesias de Francisco de Sá de Miranda, v. 263-290, Lisboa, INCM, 1989, p. 247. ${ }^{12}$ Gonzalo Anes Álvarez (ed.), La economia española al final del Antiguo Régimen: instituciones, Madrid, Alianza, 1982, p. 64 et seq.

${ }^{13 G a b r i e l ~ A l o n s o ~ d e ~ H e r r e r a, ~ A g r i c u l t u r a ~ g e n e r a l, ~ v o l . ~ I, ~ M a d r i d, ~ I m p r e n t a ~ R e a l, ~ 1818-1819, ~ p . ~} 152$. 
a time of decay, not only in agriculture but also in other arts, configured an argument of great persuasive strength for the ones who used the traditional thinking. Tacitus, in the Diálogo dos Oradores, referred that the speech was going through a deep crisis ("Who ignores the present time was far from obtaining the glory of the past?", he would ask), not for lack of right-handed men within arts, however by the laziness of the youngsters, by the negligence of parents, by the ignorance of masters and, especially, by forgetfulness or despise by the traditional values. These evils, says Tacitus, appeared in Rome and then spread through Italy and now threaten to spread over the provinces. Tacitus thought about the debate about the best preacher, described in Brutus by Cicero, a time in which the vigorous discipline of the ancestors would rise honored and distinguished men. ${ }^{14}$

Some time before, Tibullus, the favorite author by Ovid and Quintilian, complained about the lack of pax et spes (the tranquility of the present and the hope for a stable future) in which the Roman society lived in and about the unfavorable conditions for the cultivation of virtues. Horace, who had great admiration for those with spiritual aristocracy, is full of praise for Tibullus, presenting him as the one "who was dedicated to everything needed for a man to be wise and good" (Ep. I.4). Admonishing the decline of Rome, the elegies of Tibullus are exactly the counterpart of the compositions depicting the magnificence of the Roman glories and the atmosphere of general optimism in the epic phrasing of the Odes of Horace and in the Eneida of Virgil.

In the elegy I.3, Tibullus, warning the moral decay of the present, described his nostalgia of a past in which the Sheppard dreaming of owning huge fields in order to feed countless sheep. In fact, this eulogy is a lament by the fact the woman chose another (richer) suitor and moved into another property in the field, where the new lover may provide a more comfortable life. Tibullus complains that in this Iron Age, the greed and ambition reigned - the corruption of costumes - instead of sincerity and simplicity. ${ }^{15}$

In elegy I.7, written in the honor of Messalla, on the occasion of his birthday, but that refers back to his victory over the peoples of Aquitaine, says that the general, after fulfilling his civic duties successfully, could now surrender to his god Osiris (the equivalent to Dionysius and Bacchus), the god of the agriculture (the one who invented the plow and taught how to stir the soil, to sow the fields, and to reap the fruits of the trees) and wine for the Egyptians. That is, it was about time to retreat to his villa in the countryside and to take care of the administration of his rural state. The strategic reference to Isiris, on the one hand, means that the deity who created viticulture, the comforting retreat in times of peace (wine cures all ills of the body and spirit); and, on the other hand, it means the life in the country, which is the life without sadness, with joy and Grace, without the worries about the matters of civil life.

\footnotetext{
${ }^{14}$ Tacitus, Diálogo de los Oradores, Madrid, Gredos, 1988, p. 120.

${ }^{15}$ Tibulle, Tibulle et les auteurs du corpus tibullianum, Paris, Les Belles Lettres, 1955, p. 93-98.
} 
And, in elegy II.5, dedicated to Valerianus Messalla, the eldest son of Messalla, which is the longest of all the elegies of Tibullus, celebrates the founding of Rome; however, Tibullus says that before Romulus having delimited the urbs, building the insurmountable walls of the city, there was no difference between the field, the houses, and the people; the mount paladin, the temple of Apollo and fortress of the Capitol would be, then, not the symbol of splendor of the political power, but the sad contrast of this old time, peaceful and connected to nature. It is in the peasant banquet, held in the property of Valerianus, in an environment of peace among the various agriculture products harvested in the place, that one may ease the suffering and unhappiness. ${ }^{16}$

\section{This literary tradition on oeconomia, strategically withdrawn from classical texts of various kinds, at times complementary to each other, it was revived reactivated the time of Humanism}

With this same moralizing sense, the themes of agriculture and its correlates are also present in the epistles of Pliny the Younger. In epistle II.17, Pliny praises the rural state (the villa of the Laurentes), with numerous landscapes, vast plains, forests, a large cattle (horses, bulls, sheep), and with a mild weather in spring; it was neither big nor small, spending little on maintenance, with a house that serves as shelter in case of bad weather, wide, airy in order to stand the heat of the summer, cozy in winter, with provision of water and also a good provision of food (taken from the cattle and the garden), elegantly decorated with everything that is necessary for an independent life without depending on the resources of the city. In short, a life worthy of a Roman noble man. ${ }^{17}$

In epistle III.19, Pliny asks his friend Rufus, who is more experienced in the management of resources, whether or not to buy his neighbor's lands, for he had doubts about their price. He likes, particularly, the possibilities of producing agriculture - the fields are greener and fertile, despite having being abandoned lately due to carelessness.

And, more or less through his whole set of epistles, Pliny, as does Tibullus, refers to the problems addressed by the rulers of agriculture. It is about the natural phenomena, especially in the epistle addressed to Lucinius Sura, in which he asks for explanations regarding the matter of water flow and return in a water source (IV.30); praises the country house of Rufus (I.3); describes a hunting in the woods of Tuscany along with Tacitus (I.6); and lectures on the fittest slaves to rural work (I.21).

${ }^{16}$ See Tibulle, Tibulle et les auteurs du corpus tibullianum, Paris, Les Belles Lettres, 1955, p. 104-112 and also Michael Putnam, Essays on Latin Lyric, Elegy, and Epic, New Jersey, Princeton, 1982.

${ }^{17}$ Pline, le Jeune, Lettres, tome I, Paris, Les Belles Lettres, 1943, p. 83-90. 
In no other work one can read that agriculture is not limited solely to production techniques as in Sobre o pai de familia by Philo. There, he defends the argument that the primary task of a family man is to know and master oneself, without which he would not be able to properly exercise his role as the master of the home. It is immediately in the "prologue" that Philo declares, by the intervention of the "father" in his inaugural proclamation, the reasonto-be of his occupation before his family and home:

The trees of madness and licentiousness, injustice and cowardice, I shall severe entirely. I shall cut off the plants of pleasure and desire, of anger and rage and of all other uncontrolled passions, even if their branches grow to the sky. I shall burn down to ashes all its roots, letting fire consume them and I shall chase them even if buried in the hounds of hell, in order not to let a trace or shadow or part or anything at all behind. ${ }^{18}$

While it is little known and studied nowadays, all this literary tradition on oeconomia, strategically withdrawn from classical texts of various kinds, at times complementary to each other, it was strategically revived the time of Humanism. In the 16th century, Piccolomini, in his famous treaty about the criticism of the court, translated into Spanish and published in Portugal, after answering his detractors who would impute his wanting to empty the palaces of the kings and their loyal servants, cites the old example of Gyges, who was considered the most blissful and prosperous of his time. This mythical king had asked the Oracle of Apollo who was the happiest man on Earth; as it is known, the answer came immediately: it was Aglao of Arcadia, for he made an effort into perfecting his knowledge of himself through the cultivation of virtues and he was, above all, "el qual labraua vnas terrezuelas que tenia: y nu[n]ca su codicia passo de los terminos de aq[ue]lla su heredad".19

The same fable, with the identical moral meaning, is revisited by Sá de Miranda in the letter "A Pero de Carvalho". After giving a long warning against the evils of the court, against the disarrays of the insatiable greed and against "long hopes" ("vain hopes", "vacant hopes") ${ }^{20}$ in obtaining favors of the great lords, Sá de Miranda says that:

Gyges in great abundance

That all the part gathered,

Caring for so much possession,

Encouraging Apollo to question

For their bliss.

Such smoke Apollo understood,

And judged best

The one of Aglao who, being a Sheppard,

Goes on singing and plucking

With eyes on his cattle only. ${ }^{21}$

\footnotetext{
${ }^{18}$ Philo, On husbandry, London, Loeb Classical Library, 1930, p. 128.

19 "the one who harvested lands and had greed has never surpassed the limits of that heritage". Enéas Silvio Piccolomini, Miseria de cortesanos... Coimbra, luan de Barrera, 1563, fl. 237 (Seção de Obras Raras/Biblioteca Nacional do Rio de Janeiro, n. 57G,1,18).

20Francisco de Sá de Miranda, Poesias de Francisco de Sá de Miranda, vol. 103, Lisboa, INCM, 1989, p. 229; w. 296; 236. 21Francisco de Sá de Miranda, Poesias de Francisco de Sá de Miranda, vol. 61-70, Lisboa, INCM, 1989, p. 216-217.
} 
The lesson that life in the court is inclined to unreasonable passions nurturing all kinds of moral vices was the speech that Sá de Miranda delivered to one of his most beloved friends, the famous novelist Jorge de Montemayor: "No seas como muchos que sus bienes/Bien no conocen".22 Montemayor had settled in the Castillian court - well known at that time by its opulence and by the rivers of gold coming from the properties of the New World, making and unmaking fortunes - probably accompanying the infant D. Catherine for her marriage with Emperor Charles V. There, he achieved the fame of a learned man, a prestigious writer, and a rare gallantry courtier, rising in very short time to occupy great political relevance. Sá de Miranda admonished, above all, the dangers of devoting oneself to the complete irrationality of wishes, of raising reputations and favors, or even striving to obtain fame and renown in letras.

In the perspective adopted by Sá de Miranda, in order to eliminate the instability of this disproportion, in a world marked by instability and uncertainty, the best thing to do would be to immediately recognize that the true life (not the false and fickle one) is the one founded, strictly speaking, on moral freedom; only that can protect one from the setbacks of wealth and the mundane temptations of the world. However, it can only prevail if it is based on the own goods and never in the expectation of goods that depend on other people, that it, perfectly in accordance with the exemplary matrix shown by nature. Thus, this is also what Sá de Miranda advised Pero de Carvalho:

For the hungrier you come,

Dead of thirst and cold,

Fire where you want you shall find,

And the water from the river,

And the times you eat. ${ }^{23}$

In general lines, this is the same argumentative framework of the letter of Sá de Miranda “To his brother Mem de Sâ".Here, Gyges is placed side to side to the mythical Phaeton, whose petulance in driving the car of Zeus would end up calcinating his body, and of Icarus, who, deaf to the advices of paternal prudence, found his grave among the waves, as the most representative figures of this greed that infests the present time. And, in the letter "To Antonio Pereira", he states succinctly:

Oh the life of farmers,

If they knew it well

The advantages that have

Those holy sweats

That holy keep them,

Under the treatment of the old mother

Who in a while receives

(Not in mistake or bad will)

For their costume obliges them

To make more than one should. ${ }^{24}$

22"Be not as many who their goods / do not know well". Francisco de Sá de Miranda, Poesias de Francisco de Sá de Miranda, vol. 139-140, Lisboa, INCM, 1989, p. 459.

23/bidem, vol. 81-85, p. 217

${ }^{24}$ Ibidem, vol. 191-200, p. 244. 
The "good years" and the "blissful age" that Sá de Miranda recognizes as the time in which the men would dedicate themselves into obtaining wealth by agriculture (and, therefore, a time in which virtue and money are more interesting ${ }^{25}$ fit perfectly to the literary matrix contained in the main works of Virgil, an widely read and interpreted author of the 16th century in the Iberian Peninsula, especially in the lessons (mildly poetic) about the advantages and uses of agriculture, contained in the Geórgicas.

At the end of book III, Virgil describes the terrible plague affecting the field and cattle, contaminating everything it goes by. With no remedy, not even men are spared. The description of the death and rotting bodies along the plains by Virgil is particularly impressive for its vivacity. However, when opening book IV, all these ghosts of unhappiness and destruction vanish. A renewed horizon, whose purity is spread everywhere, appears. It is the "honey" as a gift running down the clouds ("caelestia dona") for the admiration of the human race.

After this, everything is ready for the new show. The dedication to Maecenas evokes peasant life and the art of agriculture, which should be loved and desired, reaffirming the project of "returning to earth" of the imperial policy of Augustus' government. And, thus, describing the favorable conditions for the onset of hives and the warlike life of bees in order to defend and aid their king, and also the free, independent, and happy life of the gardener in his little rural home, Virgil seems to metaphorically indicate the most efficient strategies for organization of political power. ${ }^{26}$ Robert Joudaux ${ }^{27}$ and Pierre Grimal ${ }^{28}$ had already drawn the attention to those biases of interpretation. It is curious to note that the sweetness and charm of the rural life, among the various perfumes of flowers, and the nobility in which farmers live (in harmony with nature), refer back to the theme of the earthly paradise. The flowers of this "arcadian atmosphere", that the poet seems to adore, and the recurring image of the perfect community organization of bees build the ideal of political peace and stability of the social order.

The literary also referred to as the Golden Age refers back to a distant past, however, Virgil, as it is known, in eclogue IV, changed the meaning of pastoral images and invested in the future as a prophetic exhortation. With the birth of such wanted child, the Iron Age comes to an end, making room to a new golden era. This new era of human kind is the culmination of a historical, spiritual, ethical, and political progression in which it is possible to invert the decline of succession and the corruption of the times. However, before the lavishness of the kingdom of Saturn settles, Virgil predicts that the world will go through a series of disasters and wars, in which the rage of the new Achilles will fall on Troy. The prophecy of Virgil is clear as for the maximum periods of suffering,

\footnotetext{
${ }^{25}$ Francisco de Sá de Miranda, Poesias de Francisco de Sá de Miranda, vol. 174, Lisboa, INCM, 1989, p. 523. ${ }^{26}$ Virgilie, Oeuvres de Virgile. P. Virgilii Maronis opera, vol. I, Paris, Hachette, 1884, p. 56-60.

${ }^{27}$ Robert Joudaux, "La philosophie politique des 'Géogirques', d’après le livre IV (v. 149 à 169)”, Bulletin de la Association Guillaume Budé, n. 1, mars 1971, p. 67-82.

${ }^{28}$ Apud René Martin, Recherches sur les agronomes latins et leurs conceptions économiques et morales, Paris, Les Belles Lettres, 1971, p. 113.
} 
of moral corruption and decay, and of all trials, so that, at last, the world gets to the Golden Age. Thus, Virgil, amidst this "millennialism", invites the puer to take up their destiny and prove their worthiness.

According to Helder Macedo, in a study on Camões, the paradise-like and "pastoral perspective", associated with a succession of ages of the world, is opposed to the warlike and apocalyptic epic matter. In this sense, the trips overseas, the conquers of peoples previously unknown, the demand for new lands, and the efforts of conquest are only used as a manifestation of the degeneration and decay of the Iron Age. ${ }^{29}$ Sá de Miranda, although he did not dismiss the military deeds as a way to obtain honor and fame for oneself and their family, shared the old thought that the desire for blood, the material greed, pillage, and plunder should never move the ones dedicated to the cultivation of virtues. Ovid, in the Metamorfoses, had already predicted, like his contemporary Virgil, that, in the times of iron and blood, the trees would come down the mountains and, would turn into boats, and would sail the seas and overcome the danger of the waves. And all that, which was previously in peace and quiet in the golden age of men (in perfect harmony and accordance), was now in complete bewilderment.

\section{Historically, this admonition literature had been widely cultivated since an early age in the European courts}

About that, the intervention of the Velho do Restelo in Os Lusiadas, in which, on the occasion of Vasco da Gama's departure to India, there is a warning on the dangers of the feats performed in name of ambition, selfishness, crave for honors, the injustices made in the name of faith, the will for glory and fame at any cost, at last, in the name of the most heinous of moral vices. Historically, this admonition literature had been widely cultivated since an early age in the European courts. And, in mid-16th century, Sá de Miranda was one of its main representatives in Portugal.

What the admonishing voice of the Velho do Restelo proposes, then, is an "ideological corrective" to the navigation adventures, that is, any effort in undertaking the Portuguese expansion overseas must be taken by means of a Christian concept of "fair war" and in harmony with the peace ideal present in the pastoral values of the Golden Age and, never, in degradation of the Iron Age. This project of peace and universal empires, whose tradition is visible in the political practices of the reign of D. Manuel, is the main contribution of Camões and the basis for the main composition of senses in his poem. Dedicated to the Portuguese king D. Sebastião, in a time when kingdom and overseas possessions found themselves in Constant danger of collapsing, Os Lusíadas

${ }^{29}$ Helder Macedo, Os Lusíadas: celebração épica como crítica pastoril. Atas da V da Reunião Internacional de Camonistas, São Paulo, USP-FFLCH, 1987, p. 117. 
states that the redemption of this politically and morally decayed present will happen necessarily through the strategical recovery of the heroism of the past. ${ }^{30}$

Sá de Miranda, in the safety of his rural retreat, would agree to the verses of Camões about the god Bacchus, figuring the eastern civilization (Indian), and all forms of excesses, as the main responsible for the atmosphere of confusion in which they lived in. It was him who, rebelling against the designs of Fortune and the orders of Jupiter, raised the intervention of the other gods. However, according to the epistles of Sá de Miranda, despite agreeing to it or not, as a rule, as the "fair war" as an activity worthy of high strain nobility, the dedication to letras ("For days I've hid,/What I read, what I wrote,/still not bored me", says Sá de Miranda to his friend Pero de Carvalho) is preferable,$^{31}$ for they are the ones who prepare the crusades to the God Cupid - not the restless flying boy, but the father of true love - , the "providential god of the pastoral machine", and the restoration of the Golden Age, as referred to in the study by Harry Levin. ${ }^{32}$

The love that Jerónimo de Contreras, in his Selva de aventuras (1542), defines is a fable. The old father, on his deathbed, decided to leave all that was his to his son who had the best opinion on women before a philosopher:

One might know that in this city had one of its richest citizens there was, named Claudius. He had three sons, whose names were: the oldest one, Ardonio; the second one, Belio; and the third one, Basurto. What happened is that among these three sons there was a great and wonderful difference, as well as the three of them were of different and strange conditions, for the oldest one, named Ardonio, is married; and the second one, named Belio, has never gotten married, but was found of an addiction called women, though being loyal to none of them; the third one, named Basurto, has never gotten married, nor even has gotten to know women, being the most in-love man of many from his time, because he says that this is what love is. ${ }^{33}$

From these three ways of love, the pastoral love will choose the third one, the one that best expresses the painful and passive attitude before love, according to the parameters of the long historical literary tradition, since the Provençal to the Iberian palace poets, going through the Italian versions of Petrarch and his followers in the poetic school of the Spanish Renaissance with Garcilaso and Boschán ahead. It is in the books of ministers that this attitude worsens through the consciousness supposing this contemplation converted in a deep insight of the movements of the soul. Sá de Miranda would choose the first kind of love; the marriage and the true friends are a part of the heritage (the "possessión" as part of the "mayordomía", as stressed by Xenophon) of the family man, although one shall agree that the first moment of ecnomy is to know oneself and strengthen the spirit before the strokes of imponderable luck.

\footnotetext{
30 José V. de Pina Martins; Eugenio Asensio, Luís de Camões, Paris, Fundação Calouste Gulbenkian, 1982, p. 30. ${ }^{31}$ Francisco de Sá de Miranda, Poesias de Francisco de Sá de Miranda, vol. 288-290, Lisboa, INCM, 1989, p. 224 ${ }^{32}$ Harry Levin, The Myth of Golden Age in the Renaissance, Oxford, Oxford University Press, 1972, p. 45. ${ }^{33}$ Apud Francisco López Estrada, Los libros de pastores en la literatura española, Madrid, Gredos, 1974, p. 179-180.
} 